\title{
過渡事象パターン解析による原子炉異常検出法の開発*
}

\author{
長田 泰典 ${ }^{* 1}$, 奈良林 直 $^{* 2}$, 辻 雅司 ${ }^{* 3}$
}

\section{Development of Abnormal Detection System by Transient Pattern Analysis}

\author{
Yasunori NAGATA*1, Tadashi NARABAYASHI and Masashi TSUJI \\ ${ }^{* 1}$ Graduate School of Hokkaido University \\ Sapporoshi, Kita-ku, Hokkaido, 060-8628 Japan
}

\begin{abstract}
Nuclear energy is fascinating on various points: enormous amount of energy, securing fuels, possibility of solving the global warming, etc. However, it's known that using nuclear energy involves dangerous and safety of nuclear power plant (NPP) is required. Study about NPP safety has been conducted by many researchers. In addition, concern for NPP safety has increased in resent years because of happening of some NPP accidents and newly establishment of NPP. In this paper, detection method of core abnormal phenomena is considered. They are: construction of this method, sensitivity analysis of transient phenomena, and examination for the validity of this method. Transient phenomena dealt with this study are: (A) small break and leak, (B) change in feedwater flow rate, (C) loss of feedwater heating. As a result, this method shows some validity to (B) and (C) but doesn't show to (A).
\end{abstract}

Key Words : Transient Phenomena, Detection System, Core Abnormal Phenomena

\section{1. 緒言}

地球温暖化やエネルギー資源の安定確保の観点から，原子力エネルギーの利用拡大が世界的に進められている が, 原子力発電所の安全確保は絶対条件である.このことは 3 月 11 日に発生した東北地方太平洋沖地震による福 島第 1 原子力発電所の事故とそれに伴う原子力災害から, 改めて強く認識される. 本研究では, 原子炉に異常が 生じた場合に, そのことが大きな過渡事象として顕在化する前の予兆の段階で検知し, 正確な情報と適切な対応 の指示を与えるような原子炉安全運転支援システムの開発を目標とした.

\section{2. 原子炉異常検知法及び本研究の目的と内容}

\section{$2 \cdot 1$ 原子炉異常検知法}

原子炉に何らかの異常が発生する場合，その状態量值には少なからず正常運転時との差異が生まれる．また， 異常の種類や発生した時の状態によってこの差異はパターン化されると思われる. そのため, この差異に注目す る事で異常原因及びその対処方法が推定できると考えた.

実際にプラントに適用する場合には図 1 に示すように，原子炉の運転と同時にこの炉と同様の応答返すように 設定した原子炉発電プラントシミュレータを作動させ, 常時この 2 つのシステムの状態量值の差異を観測する. 差異の絶対值がしきい值 $\delta$ を超えた場合には異常が発生したとし, データベースに格納されている差異パターン との比較を行い，異常原因及びその対処方法を特定する.

\footnotetext{
*原稿受付 2011 年 8 月 24 日

${ }^{* 1}$ 学生員, 北海道大学大学院（宁060-8628 北海道札幌市北区北 13 条西 8 丁目）

*2 正員, フェロー, 北海道大学大学院

*3 北海道大学大学院

E-mail: north-college-yn31@eng.hokudai.ac.jp
} 


\section{$2 \cdot 2$ 本研究の目的と内容}

本研究では(1)事故時過渡事象パターンデータベースの作成, (2)計測值と計算值の差異を用いた異常検知法の有 効性の検討を目的として定め, 原子炉運転時に起こりうる過渡事象のうち以下に示寸 4 事象 $(\mathrm{A} \sim \mathrm{D})$ に関して感度 解析を行った.
A.ダウンカマ領域における小破断漏洩
B.主給水流量減少
C.主給水流量増加
D.給水加熱喪失（低圧給水加熱器蒸気流量減少）

(1)

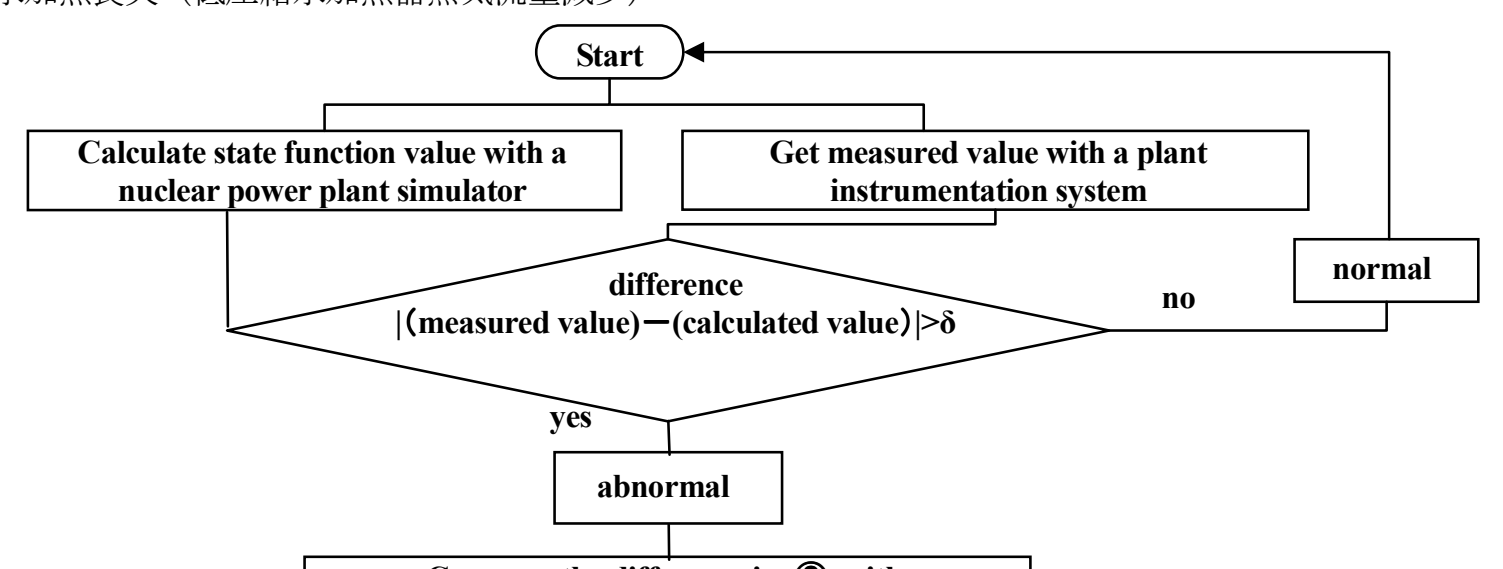

(4)

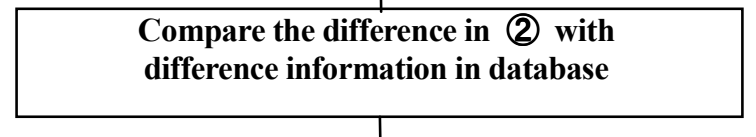

(5)

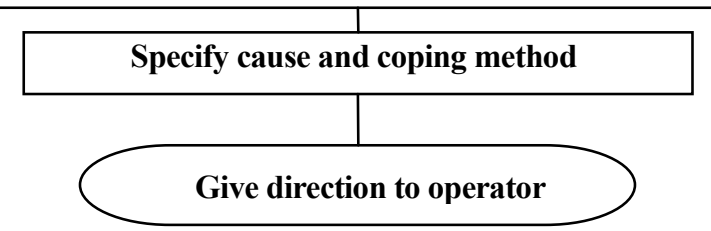

Fig.1 Flowchart for nuclear reactor abnormal phenomena detection system (Nuclear reactor safety operation support system).

\section{3. 使用シミュレータ及び感度解析条件}

\section{$3 \cdot 1$ 使用シミュレーションコード}

BWR プラント動特性解析コードである”BWRDYN”を使用した.このコードは 1989 年に JAEA(旧 JAERI) によ って小規模の異常過渡事象時のプラント状態の診断や進展予測を行う為に必要なデータを提供可能なことを目標 として開発された．本研究では 2000 年に同機関によって改良されたものを使用した.

以下にこのシミュレータの特徵を挙げる.

・中性子挙動には 1 点近似中性子動特性方程式が用いられている

・解析の高速化及び高精度化の双方を勘案して，適切なモデルの簡単化が行われている

・小破断漏洩のモデルが取り扱われている

・各種運転条件下における種々の外乱に対する過渡解析が可能

・2 次系からの外乱が原子炉の動特性に及ぼす効果について解析が可能

\section{$3 \cdot 2$ 解析モデル}

(1) 熱水力モデルに対しては, 飽和領域を 5 領域（炉心，上部プレナム，セパレータ，ドーム，自由水面領域） に分割している (図 3 参照).

(2) 未飽和領域ではエンタルピの輸送と, 飽和状態に変化した場合のボイドが水位に及ぼす効果が考慮されてい

る. 後者には気水分離モデルを用いている.

(3) 炉心は軸方向に複数のノードに分割可能で，軸方向出力分布，ボイド分布が考慮できる. 
(4) 炉心内のボイド挙動のモデル化には実験相関式によるスリップ比とスリップ速度が用いられている.

(5) セパレータ内の水量の評価にはダウンカマ水位, 蒸気クオリティ及び全流量の 3 つの効果が考慮されている.

(6) 圧力は原子炉内一様としているが，入力オプションにより蒸気ドライヤーの内側と外側の 2 領域で独立に圧 力挙動を取り扱う事により, ドライヤー内外の圧力差がダウンカマ水位に及ぼす効果を考慮できる.

（7) 再循環系はジェットポンプを有する場合と無い場合と共にモデル化されている.

(8) 1 次系内の流路は電気回路に相当するネットワークとして扱われ，それに基づく運動方程式によって炉心入 口流量及び再循環流量が計算されている.

(9) 気泡の体積と離脱速度の相関式等静的な関係式は一次遅れを援用して動的挙動に適用させている.

(10)制御系は圧力，給水流量及び再循環流量に対寸る3つがモデル化されている.

\section{$3 \cdot 3$ 感度解析条件}

原子力発電プラント Peach Bottom 2 号炉(BWR-5 型 110 万 $\mathrm{kW}$ 級)を模擬し, 下記に示すような緩慢な変化と変 化率の大きな変化を与えた. 尚, 事象発生からスクラムに至るまでを解析した.

括弧内は(緩慢な変化 / 変化率の大きな変化)として与えている.

A.小破断漏洩事象 : 破断面積 $\left(1 \mathrm{~cm}^{2}, 4 \mathrm{~cm}^{2} / 25 \mathrm{~cm}^{2}, 100 \mathrm{~cm}^{2}, 150 \mathrm{~cm}^{2}\right)$

B.主給水流量減少 : 減少率 ( $30 \min$ で-1\%,-2\%,-5\%/ 1 min で-1\%,-5\%,-10\%)

C. 主給水流量増加 : 増加率 ( $30 \mathrm{~min}$ で $+1 \%,+2 \%,+5 \% / 1 \mathrm{~min}$ で $+1 \%,+5 \%,+10 \%)$

D. 低圧給水加熱器蒸気流量減少 : 減少率 (30 min で-1\%,-2\%,-5\%/ $1 \min$ で-1\%,-5\%,-10\%)

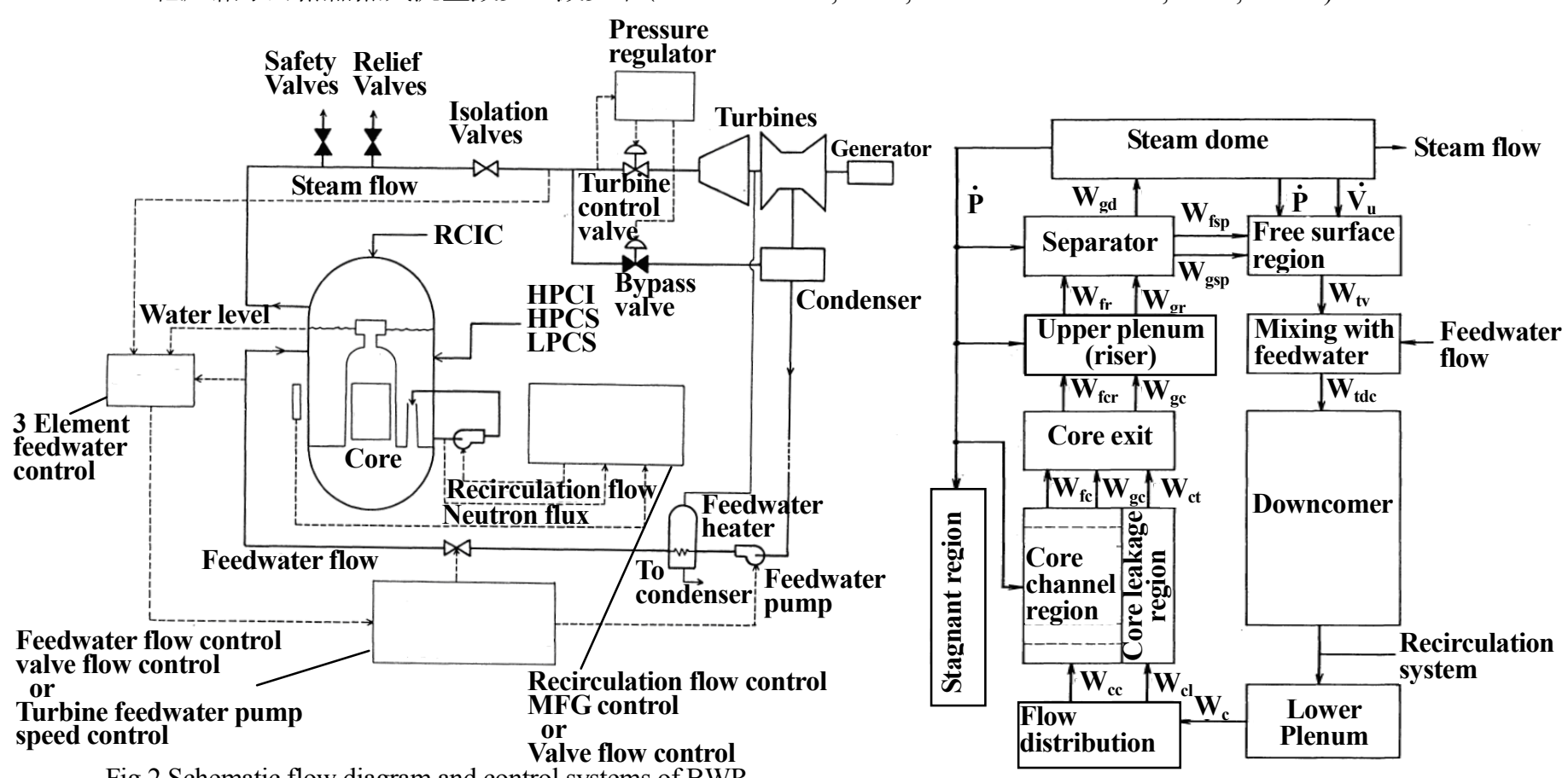
Fig.2 Schematic flow diagram and control systems of BWR plant.

Fig.3 Thermal-Hydraulic model in the reactor vessel.

\section{4. 解析結果}

\section{$4 \cdot 1$ 主給水流量減少事象}

主給水流量の減少は，図 4 に示寸ように大きく分けて 3 つの応答によって原子炉の運転に影響していくことを 確認した.

まず主給水流量が減少すると原子炉水位の低下と炉心入口サブクーリングの低下が起きた．赤枠で示す通り， 水位低下に対しスクラム条件が定められているため, この条件に達するとスクラムが発生した. 図 5, 6 のグラフ を見ると, 事象発生と同時に水位が低下し始め, 水位が $60 \mathrm{c} \mathrm{m}$ 下がった時点でスクラムしていることが分かる.

次に緑枠の応答では，サブクーリングの低下により沸騰開始位置が低下した．このため炉内ボイド量が増加， 中性子束が減少，炉心出力が低下した．図 7，8 は中性子束の時間推移を示したグラフである. 
最後に出力低下に伴い競合する応答を示した. 先の出力低下によりタービンへの蒸気流量が減少し, タービン 圧力が低下寸るため抽気流量も減少した．このため給水温度が低下し，炉心入口サブクーリングが上昇するので 炉心出力が上昇した.

競合する 2 つの応答の結果, 出力は低下した.

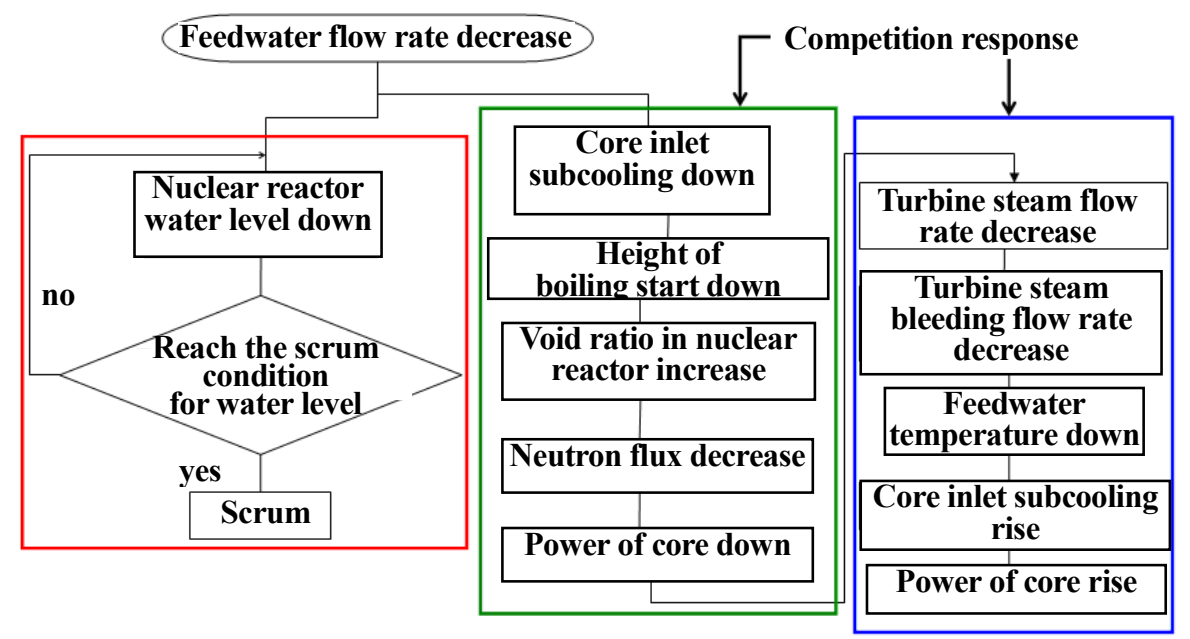

Fig. 4 influence scheme by decrease of feedwater flow rate.

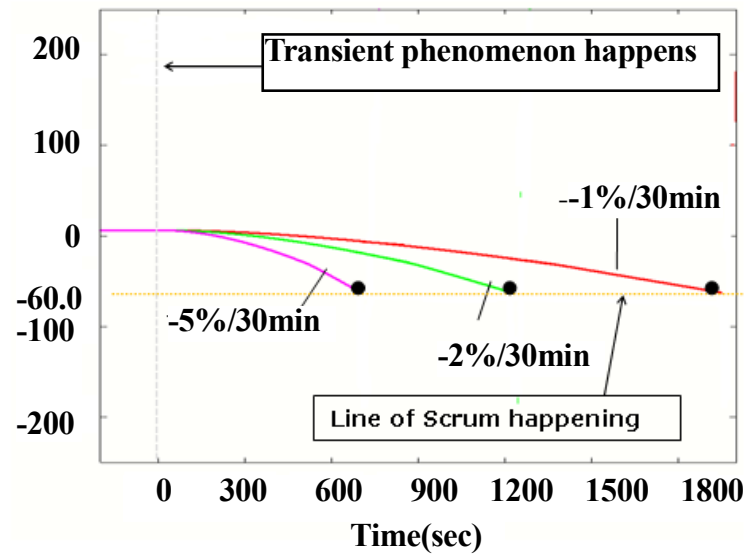

Fig.5 Graph of Reactor water level - Time (case of gradual change).

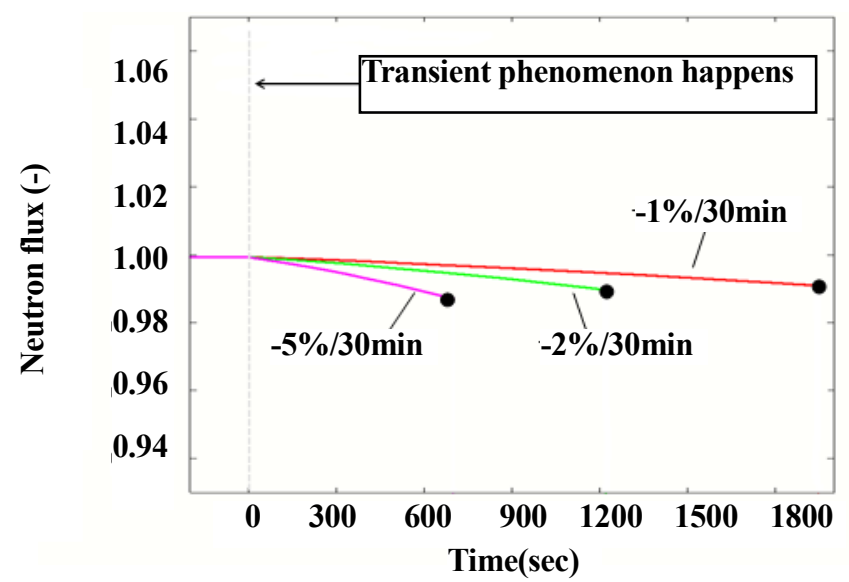

Fig.7 Graph of Neutron flux - Time (case of gradual change).

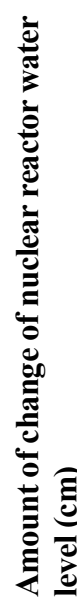

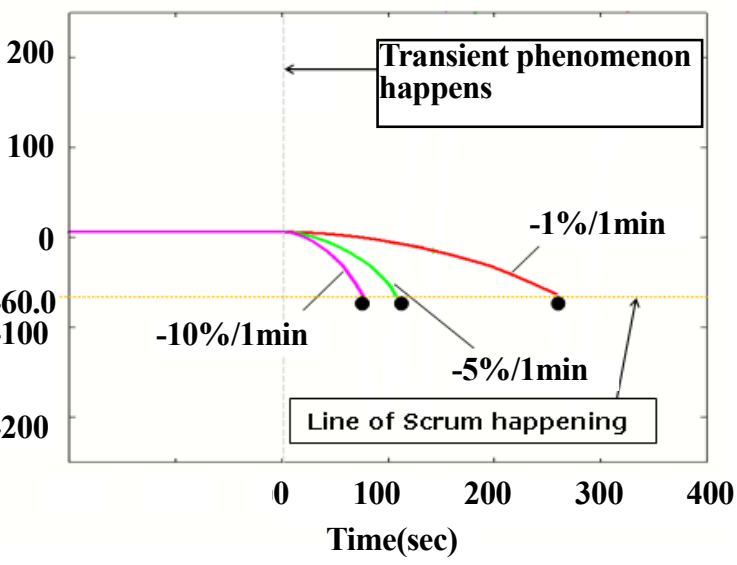

Fig.6 Graph of Reactor water level - Time (case of relatively large change).

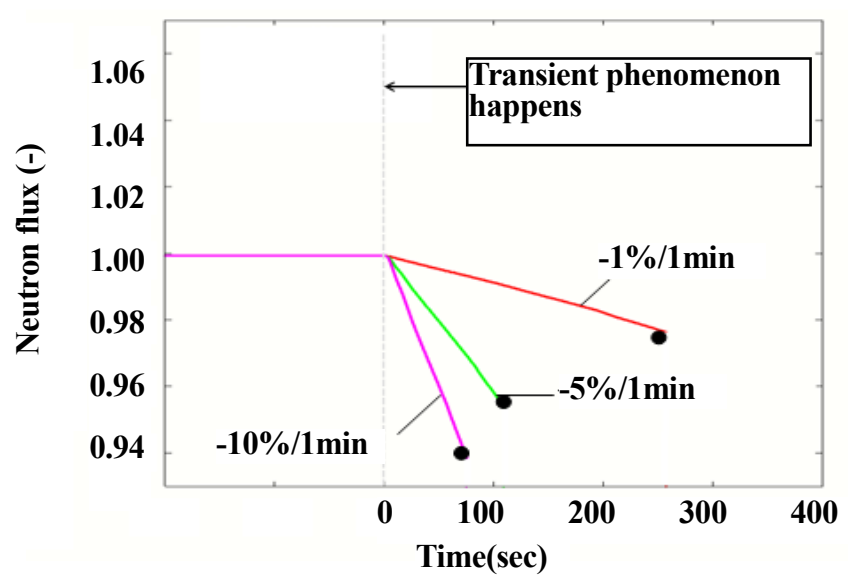

Fig.8 Graph of Neutron flux - Time (case of relatively large change). 


\section{$4 \cdot 2$ 異常検知法の有効性の検討}

今回行った緩慢な変化（破断口 $4 \mathrm{~cm}^{2} ， 30 \mathrm{~min} 2 \%$ ）における解析において，4 事象に関して代表的な状態量の過 渡事象発生から 20 分経過後の増減を色分け寸ると図 9 のようになった. 色分けの条件は下記に示寸通りである, この図から差異を用いた異常検知法を用いた小破断漏洩事象の検知は困難であり，そのほか 3 事象に関しては有 効性があることが分かった.

<色分けの条件 $>$

・(変化なし : 黄, 増加 : 赤・オレンジ, 減少 : 青・緑)

・計測系感度 : 給水流量は $0.5 \%$, それ以外の状態量は $1 \%$ 変化から計測可能

・変化量が計測系感度以下は变化なし

・変化量が計測系感度の 2 倍のものを赤あるいは青

・変化量が計測系感度以上，2 倍未満のものをオレンジあるいは緑

\begin{tabular}{|c|c|c|c|c|c|c|c|c|}
\hline & henomenon & $\begin{array}{c}\text { Neutron } \\
\text { flux }\end{array}$ & $\begin{array}{c}\text { Nuclear } \\
\text { reactor } \\
\text { pressure }\end{array}$ & $\begin{array}{c}\text { Nuclear } \\
\text { reactor } \\
\text { water level }\end{array}$ & $\begin{array}{l}\text { Feedwater } \\
\text { flow rate }\end{array}$ & $\begin{array}{l}\text { Feedwater } \\
\text { temperatu }\end{array}$ & $\begin{array}{l}\text { Turbine } \\
\text { steam }\end{array}$ & $\begin{array}{c}\text { Remarks } \\
\text { (assumptive }\end{array}$ \\
\hline A & $\begin{array}{c}\text { Small break } \\
\text { and leak }\end{array}$ & & & & & & & \\
\hline B & $\begin{array}{l}\text { Feedwater } \\
\text { flow rate } \\
\text { decrease }\end{array}$ & & & & & & & $\begin{array}{c}\text { Feedwater } \\
\text { piping break }\end{array}$ \\
\hline C & $\begin{array}{l}\text { Feedwater } \\
\text { flow rate } \\
\text { increase }\end{array}$ & & & & & & & $\begin{array}{c}\text { Abnormal of } \\
\text { control system }\end{array}$ \\
\hline D & $\begin{array}{l}\text { Loss of } \\
\text { feedwater } \\
\text { heating }\end{array}$ & & & & & & & $\begin{array}{l}\text { Steam bleeding } \\
\text { piping break }\end{array}$ \\
\hline
\end{tabular}

Fig.9 Increase and decrease 20 minutes from transient phenomena.

\section{5. 結論}

(1) 各事象による主要な状態量への影響

・小破断漏洩事象(A)は主要な状態量の変化が小さい

・主給水流量変化事象(B),(C)は原子炉水位，給水流量の変化が大きい

・給水加熱喪失事象(D)は原子炉圧力，原子炉水位以外の主要な状態量に関して十分な変化が見られる

(2) 原子炉計装系の計測精度から見たシステムの有効性

・小破断漏洩事象(A)は主要な状態量の計測自体が困難である. そのため, ドレンサンプや格納容器放射線量の 計測による異常検知が必要である

・主給水流量変化事象 $(\mathrm{B}),(\mathrm{C})$ は原子炉水位, 給水流量の 2 つに着目寸れば, 原子炉計装系で十分計測できる変 化があった．そのため，差異を用いた異常検知は可能である

・給水加熱喪失事象(D)は主要な状態量の多くに関して, 計測が十分可能な変化が見られた。 そのため差異を用 いた異常検知は可能である

\section{参考文献}

(1) 通商産業省," 4 運転時の異常な過渡変化の解析”, 東北電力株式会社東通原子力発電所の原子炉の設置に係る安全性 について, http://www2.jnes.go.jp/atom-lib/online_doc/anzensinsa/higashi/mokuji.html (参照日 2010 年 11 月 10 日)

(2) 原子力安全委員会, ”発電用軽水型原子炉施設の安全評価に関する審査指針”, http://www.nsc.go.jp/shinsashishin/pdf/1/si008.pdf, (参照日 2010 年 11 月 12 日)

(3) 横林正雄, 吉田一雄, 藤木和男, BWR プラントの動特性解析コード BWRDYN の使用マニュアル, (1989), pp.1-88, 日本原子力研究所 